\title{
Ant diversity (Hymenoptera: Formicidae) in two districts in the municipality of Barreiras-BA
}

\author{
Juliana Luiz dos Santos ${ }^{1 \bowtie \bullet}$, Greice Ayra Franco-Assis ${ }^{1 \oplus}$ \& Graziella Diógenes Vieira Marques²®
}

1. LaZooEn (Laboratório de Zoologia e Entomologia) - Universidade do Estado da Bahia - UNEB - Departamento de Ciências Humanas - DCH, Campus IX, Barreiras, BA, Brazil. 2. Secretaria Municipal de Meio Ambiente, Uberaba, MG, Brazil.

\section{EntomoBrasilis 15: e974 (2022)}

\begin{abstract}
In recent years, attention has focused on studies about myrmecofauna in urban environments, due to its high possibility of causing damage to food storage and household structures. Thus, the objective of this study was to identify the genera of ants and analyze their frequency and diversity in two neighborhoods in the municipality of Barreiras-BA. The study was conducted in Riachinho neighborhood, located on the edge of the urban perimeter and in Renato Gonçalves neighborhood in the central area of the city. The ants were collected weekly, using trap baits, in 180 houses, from November 2016 to April 2017. The collected ants were transported to the Zoology and Entomology Laboratory (LaZooEn) in the Universidade do Estado da Bahia, Campus IX. For identification, stereomicroscope and dichotomous key were used. A group of 14,846 ants were collected, of which 9,686 were collected in Renato Gonçalves neighborhood, and 5,160 in Riachinho neighborhood. Three subfamilies were identified, which included ten genera, being Paratrechina, Brachymyrmex and Tapinoma were among the most frequent. Paratrechina was the most representative (85.32\%) in Riachinho, and Brachymyrmex, the most frequent in Renato Gonçalves (54.40\%). The accumulation curves obtained were satisfactory in both areas, higher than $80 \%$. Regarding Shannon index, it was found that Riachinho presented a lower diversity $\left(H^{\prime}=0.663\right)$ than in Renato Gonçalves neighborhood $\left(H^{\prime}=0.875\right)$. Studies addressing the occurrence of myrmecofauna may be paramount to collaborate with conservation practices both in the case of threatened species and for pest control practices.
\end{abstract}

Keywords: Cerrado; Habitat; Hexapoda; Household; Urbanization.

\section{Edited by:}

William Costa Rodrigues

Article History:

Received: 18.x.2021

First Answer: 25.xi.2021

Accepted: 14.xii.2021

Published: 26.i.2022

$\bowtie$ Corresponding author:

Juliana Luiz dos Santos

乃jullianas.10@hotmail.com

Funding agencies:

$\Delta$ Without funding declared

\section{EntomoBrasillis} Updąe Check

doi: 10.12741/ebrasilis.v15.e974

(c) The Author(s) 2022. Published by Entomologistas do Brasil

This article is published by Entomologistas do Brasil and licensed under Creative Commons Licence 4.0 (CC-BY)

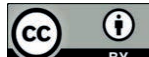

๖ Article Full Open Access
Ants are classified as eusocial insects and are inserted in a single family (Formicidae). Currently, almost 15,800 valid species, 24 subfamilies and 505 genera are known. Brazil has the greatest ants diversity across the Americas and one of the largest in the world, with 1,541 valid ant species known, distributed in 13 subfamilies and 118 genera (ANTWEB 2021). These insects are especially important organisms in the terrestrial ecosystems' performance, since they are present in almost all possible habitats (GAlleGo-Ropero et al. 2013). Furthermore, they can occupy both natural and also environments that have undergone anthropic activity (BıсHo et al. 2007).

In urban spaces, more specifically inside housing, small openings such as tiles, window trim and doorframes shelter ant nests, while in green spaces, such as gardens, nesting is found under leaves and openings in tree trunks (SOAREs 2005; Solıs et al. 2007). The relevant diversity and abundance of ants in virtually all terrestrial environments turn them into ideal organisms for rapid inventories and monitoring programs (FreITAs et al. 2006).

In recent years, attention has been turned to myrmecofauna studies in urban environments (Prezoto et al. 2017), due to its high possibility of causing damage to food storage and affecting housing structures (BuENo \& CAMPOS 2017), as also in various household objects (Costa et al. 2010). Hence, it is necessary to analyze the occurrence of ants in different types of urban environments, besides understanding the risks that they can offer in housing. For instance, ants belonging to Camponotus genus are common inside houses, causing damage to residential structures and appliances (BUENo \& CAMPOS 2017). Thus, the aim of this study was to identify the ant genera and analyze their frequency and diversity in households in two neighborhoods in the city of Barreiras-BA.

\section{MATERIAL AND METHODS}

The present study took place in the city of Barreiras-BA $\left(12^{\circ} 09^{\prime} 10^{\prime \prime} \mathrm{S} / 44^{\circ} 59^{\prime} 24^{\prime \prime} \mathrm{W}\right)$ located in the extreme west of Bahia. Intended for the development of the research, two urban neighborhoods were selected, one in the central area, called Renato Gonçalves $\left(12^{\circ} 09^{\prime} 15^{\prime \prime}\right.$ $\left.\mathrm{S} / 44^{\circ} 59^{\prime} 38^{\prime \prime} \mathrm{W}\right)$, and another one in the neighborhood named Riachinho (12 ${ }^{\circ} 8^{\prime} 28^{\prime}$ ' $\mathrm{S} /$ $44^{\circ} 54^{\prime} 33^{\prime \prime} \mathrm{O}$ ), which is located on the edge of the urban perimeter and is located at $11.8 \mathrm{~km}$ apart from the first neighborhood (Figure 1).

Renato Gonçalves neighborhood (Figure 2) was chosen since there is a larger paved area with high buildings, commercial areas and an afforestated structure, in addition to the presence of green areas around the residences. Riachinho neighborhood (Figure 3) is an area integrated into the urban perimeter, whereby there is still no asphalt pavement. Nevertheless, it has a larger vegetation area (trees, shrubs and pastoral activity), as there are 


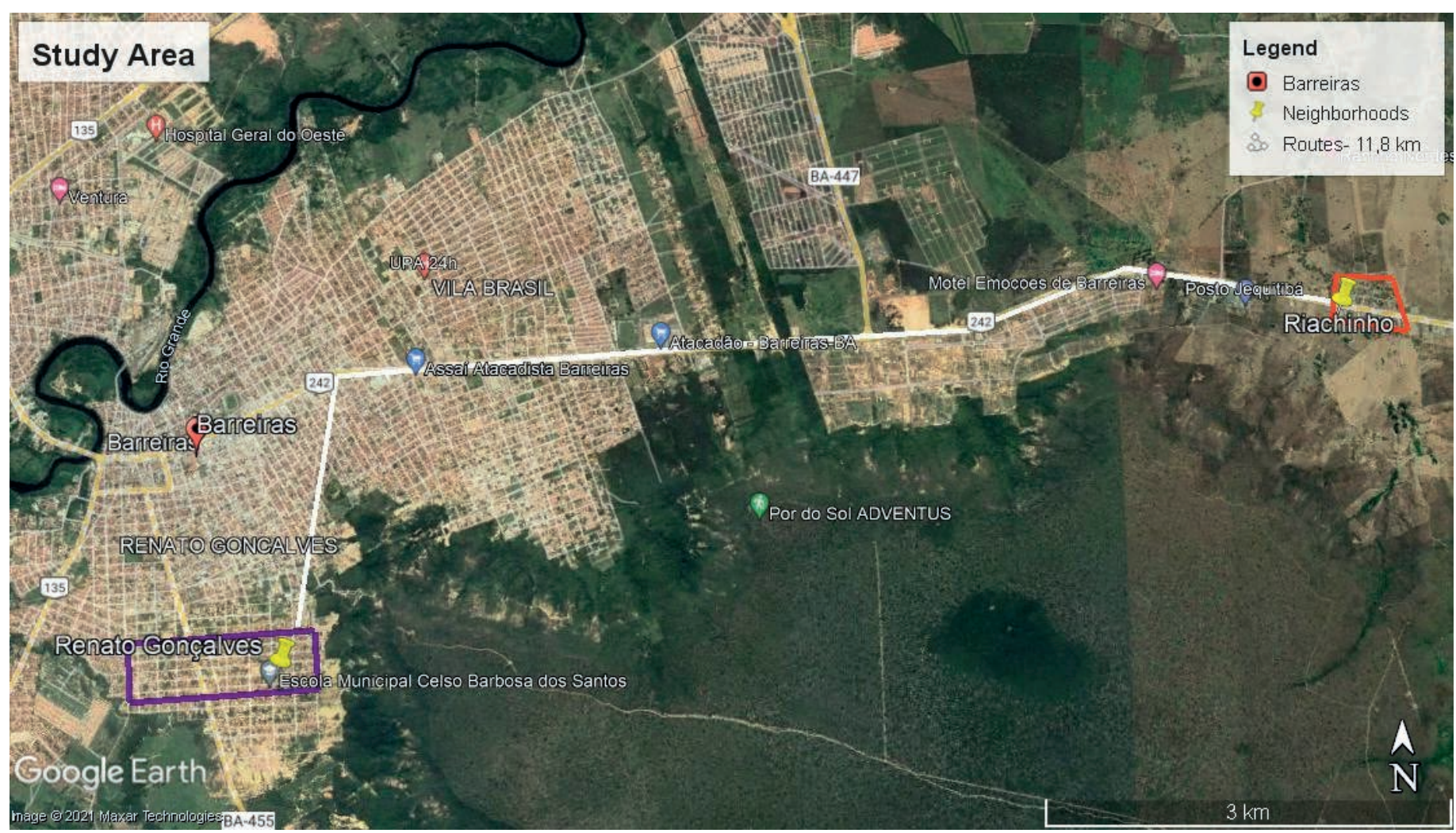

Figure 1. Distance between Renato Gonçalves and Riachinho neighborhoods, Barreiras-BA, 2016. Source: Google Earth.

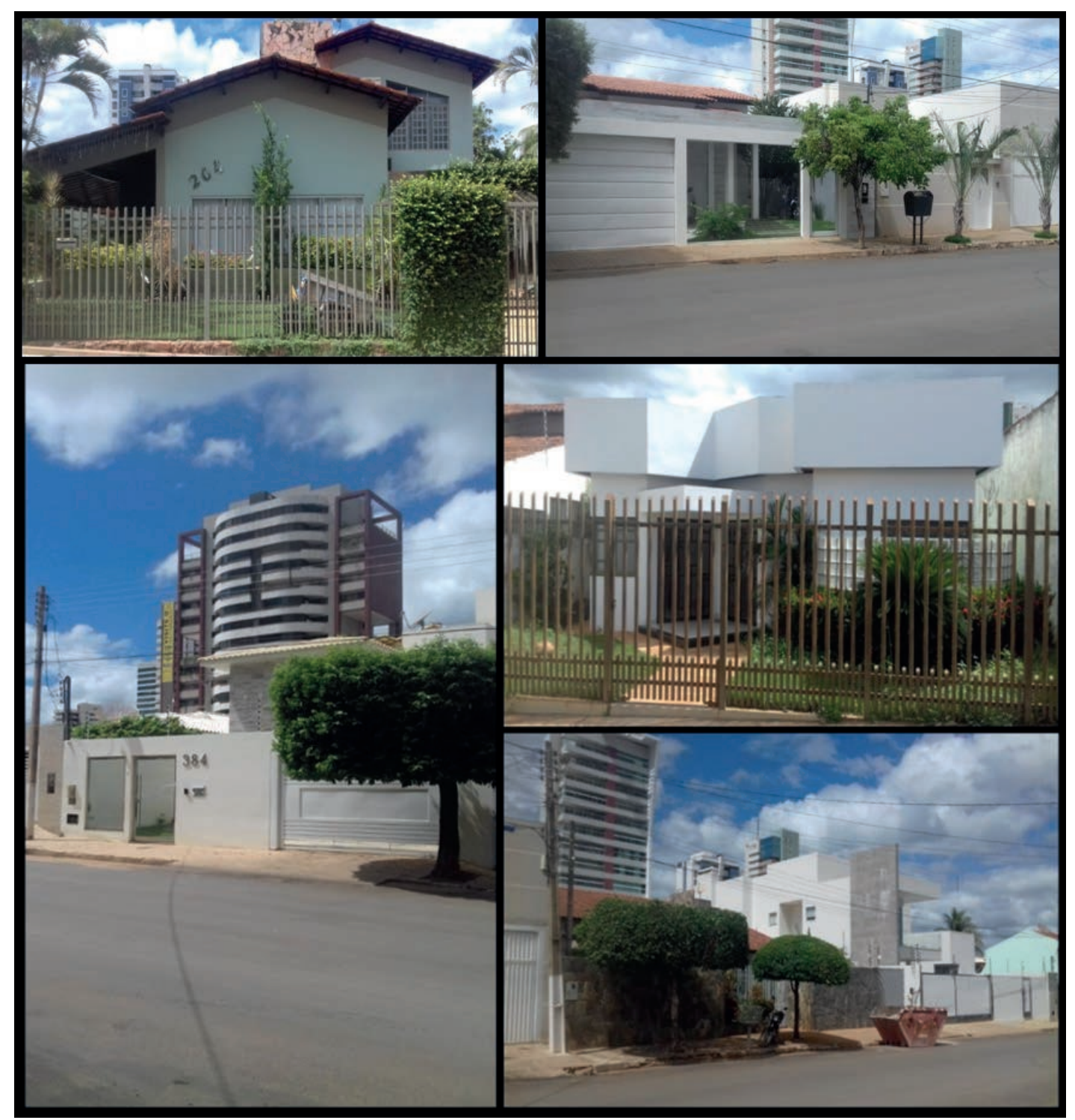

Figure 2. Renato Gonçalves neighborhood located in the central area of Barreiras-BA municipality, 2016/2017. Photos: Santos, J. 2016/2017. 
rural properties that surround it. The buildings are made of simple masonry (slabless houses; no ceramic floor; external bathroom; presence of wire and/or wood fence delimiting the residences) and there is a restricted commercial area.

In order to survey myrmecofauna, 18 collections were carried out in each of the neighborhoods from November 2016 to April 2017. As to capture the ants, applying the bait trap model used by SOAREs et al (2006), was necessary.

The collection was carried out three times a month in five houses chosen randomly in each neighborhood, comprising a total of 180 houses sampled. For making the traps, a 10 $\mathrm{cm}$ height glass container was used, which was covered by a plastic lid, which center was perforated within a $1.5 \mathrm{~cm}$ diameter. In the center of this plastic lid, a plastic tube was placed, about $6.5 \mathrm{~cm}$ of height, which could not reach the bottom of the container (Figure 4). The liquid bait, made using a sugary chamomile solution, was placed inside the container (Figure 4) and subsequently, each trap was placed in the residences, in the following rooms: kitchen, bathroom, living room and bedrooms. Those traps were kept in the

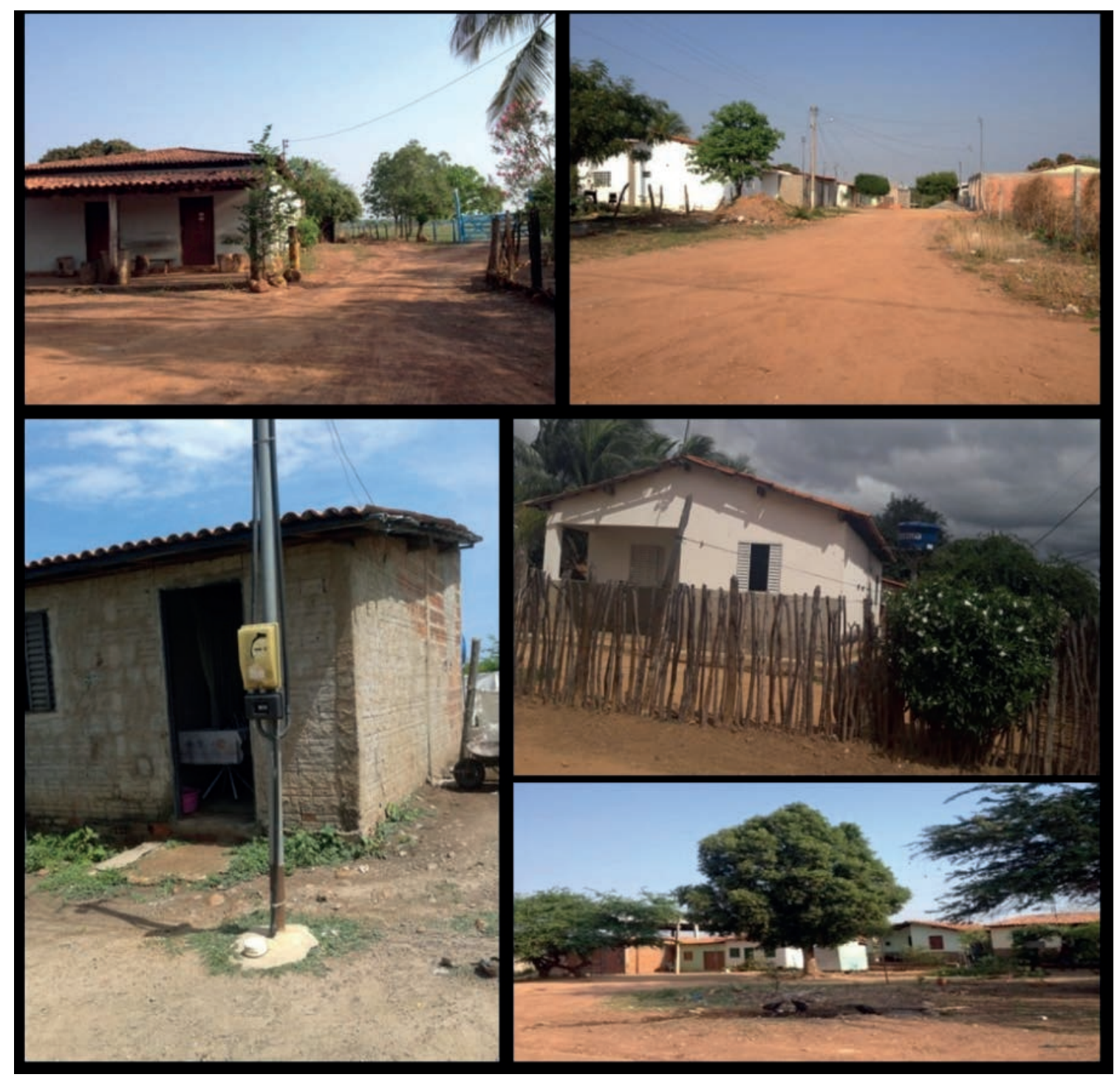

Figure 3. Riachinho neighborhood located in urban area of Barreiras-BA municipality, 2016/2017. Photos: Santos, J. $2016 / 2018$.

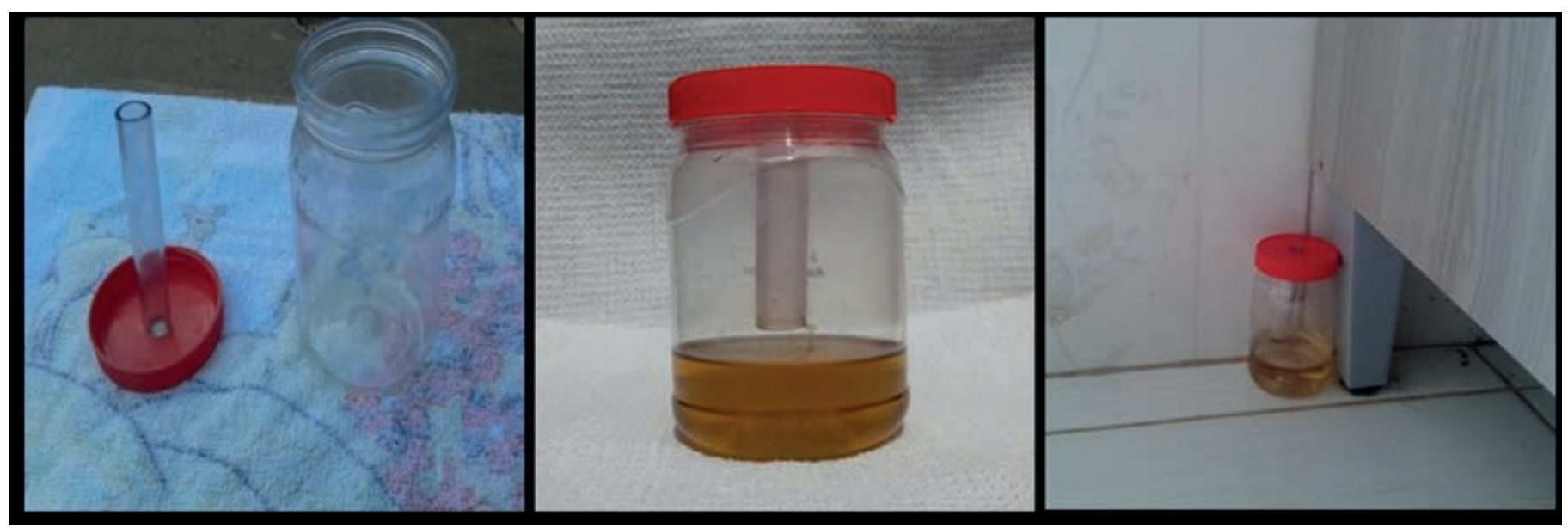

Figure 4. Trap used to collect ants in residences located in Renato Gonçalves and Riachinho neighborhoods, Barreiras-BA municipality, 2016/2017. Photos: Santos, J. 2016/2017 
rooms for a period of $24 \mathrm{~h}$ (Figure 4).

The ants were collected and transported to the Zoology and Entomology Laboratory-LaZooEn, Universidade do Estado da Bahia-UNEB, Campus IX. For identification at the genus level, a stereomicroscope and the dichotomous key by BAccaro et al. (2015) were used, after that they were kept in the laboratory as voucher material.

Relative and absolute frequencies were utilized to show the genera occurrence and Shannon's index $\left(\mathrm{H}^{\prime}\right)$ was chosen in order to assess the diversity parameters between the neighborhoods. As for testing the results found in both areas, Mann-Whitney $U$ Test was applied, since the data stated did not follow a normal distribution. Excel® software spreadsheets were used in the analysis of relative and absolute frequencies, Mann-Whitney and diversity index. The study collections sufficiency was verified by means of accumulation curves, applying Estimate $\triangle \circledR$ software, version 9.1 (Colwell et al. 2012) and the used estimators were CHAO 1 and ACE.

\section{RESULTS AND DISCUSSION}

A total of 14,846 ants were collected, 5,160 in Riachinho area and 9,686 in Renato Gonçalves area, distributed into three subfamilies (Formicinae, Myrmicinae and Dolichoderinae) and 10 genera (Table 1).

The accumulation curves obtained had efficient collections in both neighborhoods, that is, the sampling effort was sufficient to sample the set of ant genera. CHAO 1 and ACE indexes for Riachinho showed $100 \%$ efficiency in both indexes (Figure 5), while the efficiency in Renato Gonçalves was $97.30 \%$ and $87.63 \%$, respectively (Figure 6). When investigating the literature, it was not possible to find current studies that work at the genus level, what there has been about ant studies in urban areas are surveys at the species level, which also were efficient in their sampling. For instance, on an island in Florianópolis, an ant survey was carried out with 80 species, and the accumulation curve found was $95.93 \%$, considered sufficient (Cereto et al. 2009). Another example is that in MiRANDA et al. (2006) who also found a satisfactory sampling effort using attractive baits (sardines and honey), in a myrmecofauna study (with 26 species), carried out in Araguari local park, located in an urban area. lop et al. (2009) evaluated myrmecofauna present in residences and commercial areas (67 species) in Xanxerê municipality, Santa
Catarina State and the estimated values of ant richness were satisfactory, since the accumulation curves (67 and $74.12 \%$ ) showed a stability approximation.

The most expressive subfamily in terms of number of individuals was Formicinae, followed by Dolichoderinae and Myrmicinae (Figure 7). Formicinae with its 13,945 individuals is distributed in the following genera: Camponotus, Nylanderia, Brachymyrmex and Paratrechina in both neighborhoods. Among them, Paratrechina stood out with the largest number of individuals in Riachinho.

Myrmicinae showed the greatest diversity of genera (Table 1), with Pheidole and Ochetomyrmex being found only in Renato Gonçalves, while Tetramorium only occurred in Riachinho. The genera Wasmannia and Monomorium, in turn, were found in both studied neighborhoods. The subfamily Dolichoderinae was represented only by the genus Tapinoma, which had the highest absolute frequency in Riachinho.

Using a collection technique (Pitfall) and a different environment, Oliveira et al. (2016), when comparing the edaphic myrmecofauna in three successional stages of Atlantic forest (forest, scrub and pasture), they identified 1,157 ants, distributed in 14 genera. Myrmicinae presented a total of $283(24.46 \%)$ ants, grouped into five genera, nevertheless, Formicinae subfamily was the most abundant, with 371 (32.06\%) individuals, represented by Camponotus genus (Table 1). BAIOTTo et al. (2015) carried out a study in three points of Northwest Regional University of State of Rio Grande do Sul. The area close to the Veterinary Hospital entrance, one of the points, had the highest number of ants. A total of 274 ants were registered, with 84 (30.65\%) representing Myrmicinae subfamily and 92 (33.57\%), Formicinae. This area presented greater availability as food source and nesting site. The study was conducted over an 11-day period, with 3-4 days intervals between collections, which may justify the discrepancy with the current study (Table 1). BAcCARO et al. (2015) explain that Formicinae is a subfamily that holds genera with a wide abundance of individuals and that these are extremely easy to be collected. Such characteristics may justify the high diversity of Formicinae in the present study.

According to some authors (Ramos et al. 2003; DoRval et al. 2017), in areas of Cerrado, the presence of Myrmicinae ants has a high occurrence rate, followed by the subfamily Formicinae. This abundance is due to the fact that they are two subfamilies with easy adaptation to different types of

Table 1. Absolute (F. A.) and relative (F. R.) frequency of collected insects in housing environments in Riachinho and Renato Gonçalves neighborhoods, Barreiras-BA municipality, throughout the period of November 2016 and April 2017.

\begin{tabular}{|c|c|c|c|c|c|c|c|}
\hline \multirow{2}{*}{ Subfamily } & \multirow{2}{*}{ Genus } & \multicolumn{2}{|c|}{ Riachinho } & \multicolumn{2}{|c|}{ Renato Gonçalves } & \multirow{2}{*}{ Total F.A. } & \multirow{2}{*}{ Total F.R } \\
\hline & & F. A. & F.R. & F.A. & F.R. & & \\
\hline \multirow{4}{*}{ Formicinae } & Camponotus & 118 & 2.28 & 53 & 0.54 & 171 & 1.15 \\
\hline & Nylanderia & 3 & 0.05 & 2 & 0.02 & 5 & 0.03 \\
\hline & Brachymyrmex & 85 & 1.65 & 5,273 & 54.40 & 5,358 & 36.09 \\
\hline & Paratrechina & 4,402 & 85.32 & 4,009 & 41.35 & 8,411 & 56.65 \\
\hline Total & 04 genus & 4,608 & 89.3 & 9,337 & 96.31 & 13,945 & 93.92 \\
\hline Dolichoderinae & Tapinoma & 238 & 4.62 & 221 & 2.25 & 459 & 3.10 \\
\hline Total & 01 genus & 238 & 4.62 & 221 & 2.25 & 459 & 3.10 \\
\hline \multirow{5}{*}{ Myrmicinae } & Monomorium & 35 & 0.68 & 2 & 0.02 & 37 & 0.02 \\
\hline & Wasmannia & 166 & 3.21 & 1 & 0.01 & 167 & 1.13 \\
\hline & Tetramorium & 113 & 2.19 & - & - & 113 & 0.76 \\
\hline & Ochetomyrmex & - & - & 115 & 1.18 & 115 & 0.78 \\
\hline & Pheidole & - & - & 10 & 1.03 & 10 & 0.07 \\
\hline Total & 05 genus & 314 & 6.08 & 128 & 2.24 & 442 & 2.76 \\
\hline Total & & 5,160 & 100 & 9,686 & 100 & 14,846 & 100 \\
\hline
\end{tabular}




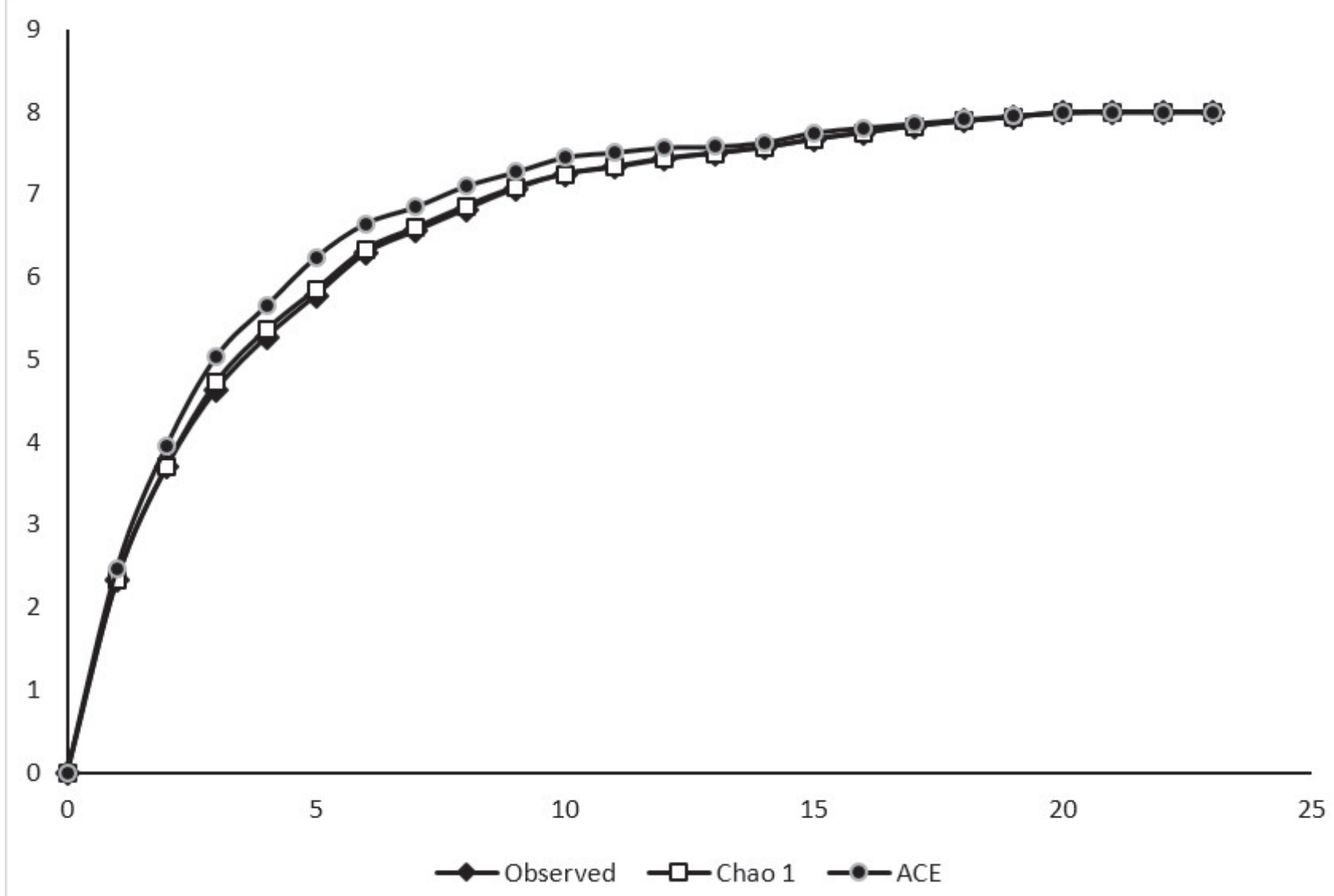

Figure 5. AntAnt collection accumulation curve in Riachinho neighborhood, 2016/17 in Barreiras-BA municipality. The curve was produced by EstimateS software (CoLweLL et al. 2012).

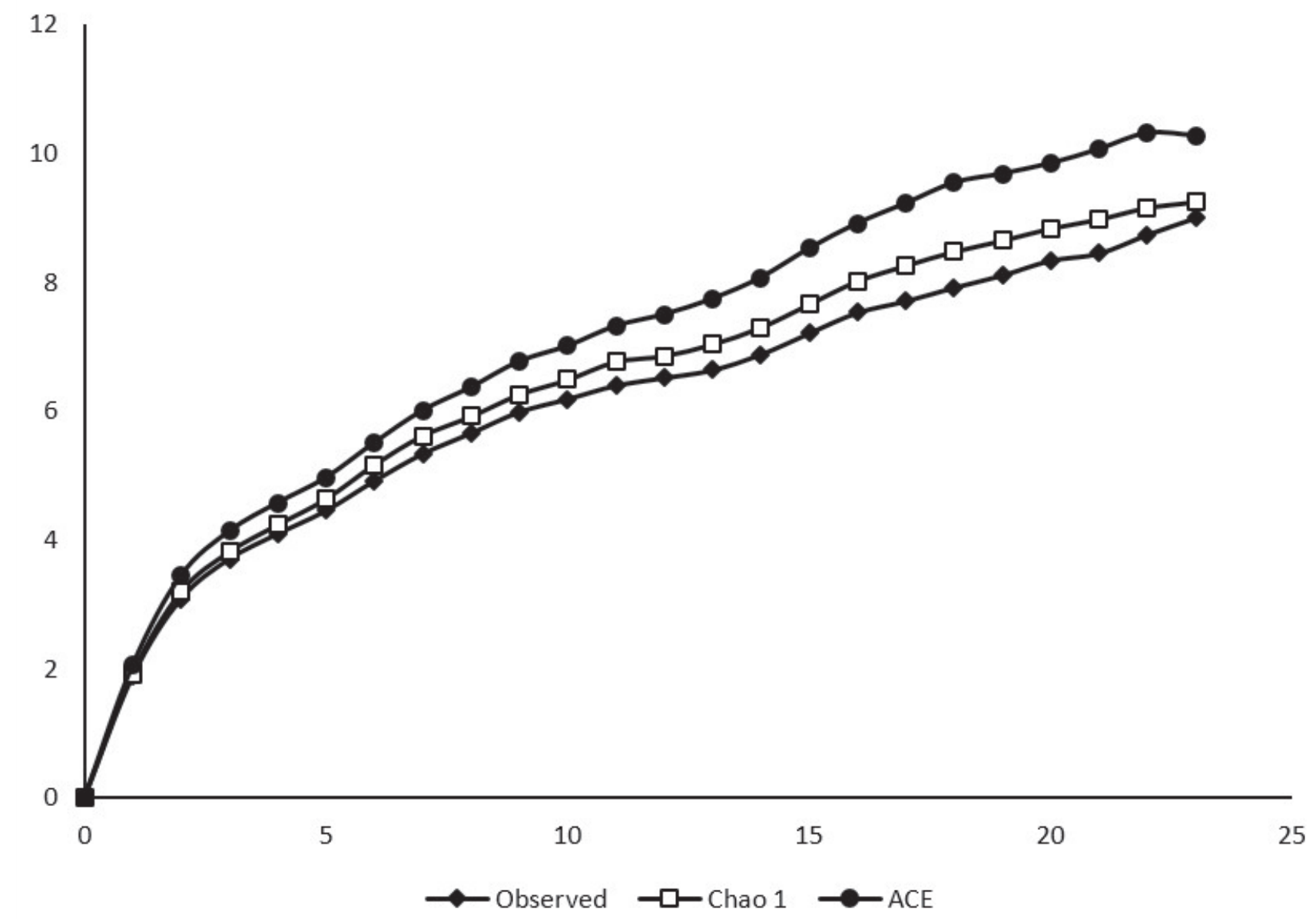

Figure 6. Ant collection accumulation curve in Renato Gonçalves neighborhood, 2016/17 in Barreiras-BA municipality. The curve was produced by EstimateS software (Colwell et al. 2012). 


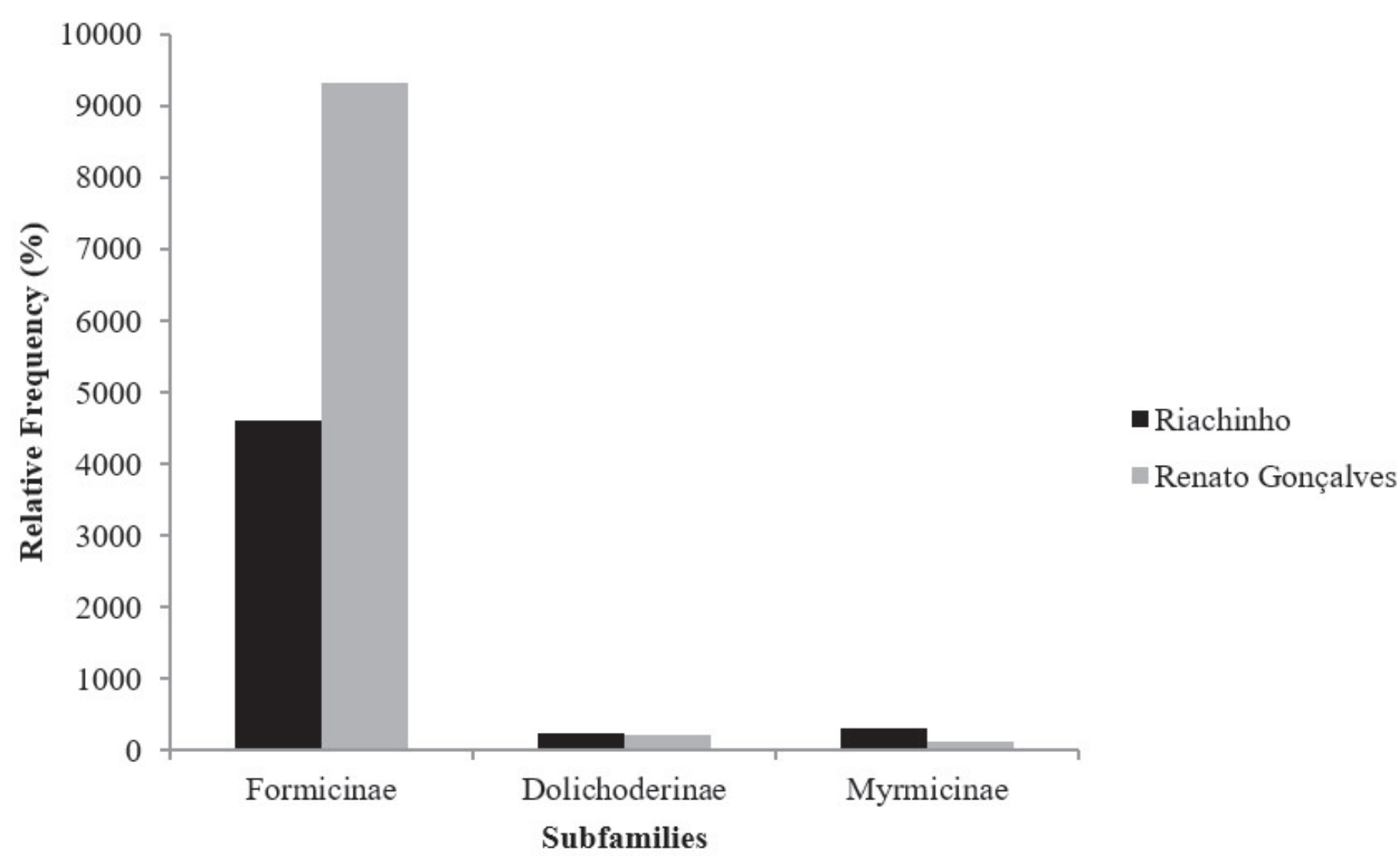

Figure 6. Ant subfamilies relative frequency (\%) in Riachinho and Renato Gonçalves neighborhoods, Barreiras-BA, throughout the period of November 2016 and April 2017.

environments. Just as this study identified Myrmicinae and Formicinae standing out in numbers of individuals, a survey carried out by OLIVEIRA \& CAMPOS-FARINHA (2005) pointed out these taxo groups as being the most frequent in household areas. According to BUENO \& CAMPOS (2017), the urban environment has its own abiotic factors, which biologically benefits the appearance of many animal species, including hundreds of ant species, mainly due to the high human concentration and water and food availability.

The genera with the highest relative frequency were Paratrechina (56.65\%), Brachymyrmex (36.09\%) and Tapinoma (3.10\%) (Table 1), which are characterized as opportunistic and even urban pests (CASTRO et al. al. 2014; BACCARO et al. 2015). In addition to the wide food supply, other factors contribute to the occurrence of these insects inside residences, such as size, number of workers in recruitment, nesting space and ease of inhabiting different types of environments (CINTRA-SOCOLOWSKI \& BUENo 2017). The presence of Paratrechina, Brachymyrmex and Tapinoma in the housing environment was also described by SOARES et al. (2006), when carrying out a survey of ants' diversity in the municipality of Uberlândia, in Minas Gerais State. These individuals are easy to adapt to highly anthropized areas and can be found both in low-vegetated forest environments and in households (BACCARO et al. 2015; Rocha et al. 2015).

According to BAcCARO et al. (2015) and Bueno (2017), Paratrechina, which in the present study showed the highest relative frequency (Table 1), is a cosmopolitan genus that inhabits both disturbed natural environments and urban spaces. These insects usually build their nests outside infested places, such as in home gardens, recruiting large numbers of workers and a colony can comprise several queens (CINTRASOCOlOWSKI \& Bueno 2017; HerRera et al. 2020). According to JúNIOR (2017), its presence is common in environments such as soil, vegetation in houses, parks and urban fragments. As for BACCARO et al. (2015), these are opportunistic ants, which feed on leftover fruit and household food.

Cintra-Socolowski \& Bueno (2017) highlight that Brachymyrmex are reduced-size ants (0.2 to $0.4 \mathrm{~mm}$; Suguituru et al. 2015), as well as the genus Paratrechina $(0.2$ to $0.5 \mathrm{~mm}$; BACCARO et al. 2015). They are insects with several queens and also recruit a large number of workers. Brachymyrmex nests can be found on tiles or on cabinet and/or door frames. Due to their easy adaptation in different environments, the occurrence of these insects is common both in vegetation areas with different levels of degradation, as well as in an urban environment (Rocha et al. 2015; Lutinski et al. 2017). SiLVA \& LoECK (1999) pointed out this same genus with a high rate of infestation inside the sampled households in the city of Pelotas, Rio Grande do Sul State. According to the authors, among the genera collected in the research, Brachymyrmex stood out, being found indoors and outdoors. It is noteworthy that in the present study, the collections were carried out only inside the houses. LUTINSKI et al. (2017) explain that the size of these insects and the foraging activity in large numbers of individuals favors dominance by food source and nesting in indoor and outdoor areas of urban environments.

The genus Tapinoma for having a tiny size, ranging from 0.1 to $0.5 \mathrm{~mm}$ and due to the colorless gaster coloration, they can go unnoticed (CARValmo et al. 2011; Cintra-Socolowski \& BUENO 2017) indoors, which explains the frequency of these insects in the areas studied. According to Melo \& Dellabie (2017), Tapinoma ants occur in more than $50 \%$ of cities and are considered invasive, due to the ease of being found in a greater number of habitats.

As for the samples collected in Riachinho and Renato Gonçalves neighborhoods $(U=47 ; p>0.001)$, there was no significant difference, that is, the location (neighborhoods) did not influence the occurrence of ants during the study. In a survey carried out in the urban perimeter of Juiz de For a city Minas Gerais State, with the same statistical test used (MannWhitney $U$ Test), it also showed that there was no significant difference for the samples taken. The research took place in urban areas where a comparison was made between three squares close to the urban center and another three in more 
distant places (VITAL 2007). Ant diversity in paved areas is probably due to species considered opportunistic, sensitive to disturbance from urbanization (MoRINI et al. 2007; VITAL 2007).

Thus, even if the homes have different physical structures, nesting construction inside housings will not be affected, as a significant number of ants was found between the neighborhoods. Thus, the location of the studied areas does not interfere with the occurrence and propagation of these insects within the residences (SOARES 2005).

Riachinho neighborhood $\left(H^{\prime}=0.663\right)$, presented lower diversity than Renato Gonçalves neighborhood $\left(H^{\prime}=0.875\right)$. RoANI et al. (2019), explain that the result of diversity is due to the sampling effort. This and other factors such as the used methodology, and the environment for collection can interfere in the ant richness. Here, the sampling effort was sufficient (Figures 5 and 6), which highlights the low diversity of urbanized environments.

According to Prezoto et al. (2017), many animals are forced to live off the resources offered by anthropized environments. This fact is due to the partial or complete loss of their habitats, whether conserved or restored urban areas, where they take full advantage of the shelter and food provided by human beings.

Renato Gonçalves neighborhood was the one presenting the highest number of genera, probably because of the offer of shelter and food in the same area. The presence of gardens around the houses, as well as the availability of food inside the houses, may be factors that contribute to the growth of the ant population.

PACHECO et al. (2017), report that the lack of natural predators facilitates the spread of these insects in urban spaces. This characteristic can justify the result found in the studied areas, where, in Renato Gonçalves neighborhood, as it is an area located in the center of the city, the presence of natural enemies may be smaller. Riachinho neighborhood, where the number of ants found was lower, has a high level of secondary vegetation, which facilitates the presence of natural enemies, and consequently may lead to a low occurrence of ants.

Bueno \& CAMPOS (2017), also point out that many urban ants inhabit extremely clean spaces, having difficulties to live in dirty environments, which characterizes them as indicators of cleanliness. This may justify the greater number of ants in Renato Gonçalves neighborhood, since, as this is an area located in the central region of the city, solid waste collection takes place more frequently (three times a week), while that in Riachinho neighborhood, where collection is carried out once a week, according to the locals.

Another aspect that can be considered is the use of chemical products in an attempt to reduce insect infestation problems. On the other hand, it is important to know the feeding habits of a given species of ant, as some genera such as Paratrechina and Bachymyrmex are hardly controlled with the use of insecticides (CINTRA-SOCOLOWSKI \& BUENo 2017).

Some genera described in this research, such as Paratrechina, Monomorium, Nylanderia, Pheidole and Wasmannia have species considered invasive, tolerant to disturbances and can be commonly found in urban environments (LUTINSKI et al. 2014). JAIME (2010) points out that the lack of asphalt pavement and the presence of gardens can increase ant species richness. Differing to this study, the most diverse neighborhood observed in this research, Renato Gonçalves, has gardening and asphalt paving, while Riachinho, less diverse, the streets are not yet paved.

Studies that address myrmecofauna can be essential not only for understanding their natural histories, but also for collaborating with conservation practices both in the case of endangered species and for pest control practices, such as invasive species.

CALDART et al. (2012) emphasize that studies on urban ants are of special interest, as they make it possible to list the species that live in these environments, and to assess the impact of urbanization process on myrmecofauna. Thus, the results of this study show the importance of keeping myrmecological research in an urban area in the city of Barreiras-BA, contributing to greater information and understanding about ant communities.

\section{ACKNOWLEDGEMENTS}

Universidade do Estado da Bahia-UNEB, Campus IX.

\section{REFERENCES}

AntWeb, 2021. Versão 8.66. California Academy of Science. Available in: <https://www.antweb.org>. [Access: 07.xii.2021].

Baccaro, FB, RM Feitosa, F Fernández, IO Fernandes, TJ Izzo, JD Souza \& R Solar, 2015. Guia para os gêneros de formigas do Brasil. 2 Edição. Manaus: Editora INPA.

Baiotto, EW, FK Santos, MT Squalli, V Bianchi \& J Siede, 2015. A riqueza de subfamílias de Formicidae (Hymenoptera) presentes no solo do campus da Universidade Regional do Noroeste do Estado do Rio Grande do Sul, Ijuí, RS, Brasil. XX Jornada de pesquisa, 20: 1-6.

Bicho, CL, MLC Brancão \& SM Pires, 2007. Mirmecofauna (Hymenoptera, Formicidae) em hospitais e postos de saúde no município de Bagé, RS. Arquivos do Instituto Biológico, 74: 373-377. DOI: https://doi.org/10.1590/18081657v74p3732007

Bueno, OC, 2017. Criação de formigas em laboratório, pp. 125-142. In: Bueno OC, AEC Campos \& MSC Morini, (Eds). Formigas em ambientes urbanos no Brasil. São Paulo: Canal 6 Editora.

Bueno, OC \& AEC Campos, 2017. Formigas que vivem no Ambiente urbano, pp. 31-48. In: Bueno OC, AEC Campos \& MSC Morini, (Eds). Formigas em ambientes urbanos no Brasil. São Paulo: Canal 6 Editora.

Caldart, VM, S Iop, JA Lutinski \& FRM Garcia, 2012. Diversidade de formigas (Hymenoptera, Formicidae) do perímetro urbano do município de Chapecó, Santa Catarina, Brasil. Revista Brasileira de Zoociências, 14: 81-94.

Carvalho, APR, CG Silva \& AR Fonseca, 2011. Diversidade de formigas em um hospital público no município de Chapadinha, Maranhão, Brasil. Revista de Biologia e Ciências da Terra, 11: 67-73.

Castro, MM, EF Fernandes, HH Santos-Prezoto \& F Prezoto, 2014. Formigas em ambientes urbanos: importância e risco à saúde pública. Ces Revista, 28: 103-117.

Cereto, CE, MA Ulysséa, FF Albertoni, AG Martins \& BC Lopes, 2009. Mirmecofauna associada a distintas fitofisionomias de restinga na Ilha de Santa Catarina, Florianópolis, sul do Brasil. III Congresso Latino Americano de Ecologia, 3: 1-4. Available in: <https://www.seb-ecologia.org.br/revistas/ indexar/anais/2009/resumos_clae/328.pdf>.

Cintra-Socolowski, P \& OC Bueno, 2017. Formigas em ambientes hospitalares, pp. 667-685. In: Bueno OC, AEC Campos \& MSC Morini, (Eds). Formigas em ambientes urbanos no Brasil. São Paulo: Canal 6 Editora.

Colwell, RK, A Chao, NJ Gotelli, SY Lin, CX Mao, RL Chazdon \& JT Longrino, 2012. Models and estimators linking individualbased and sample-based rarefaction, extrapolation, and comparison of assemblages. Journal of Plant Ecology, 5: 3-21. DOI: https://doi.org/10.1093/jpe/rtr044

Costa, EM, MA Filgueira, FL Oliveira, JAM Araújo \& NB Lima, 2010. Estudos preliminares sobre a mirmecofauna urbana 
de Mossoró-RN: identificação dos gêneros. Revista Verde, 5: 151-156.

Dorval, A, O Pires-Filho, VC Jorge, MD Souza \& WO Rocha. 2017. Diversidade de formigas em fragmento de Cerradão submetido à exploração de madeira em Cuiabá, MT. Revista Espacios, 38 31: 1-3.

Freitas, AVL, IR Leal, M Uehara-Prado \& L Iannuzzi, 2006. Insetos como indicadores de conservação da paisagem, pp. 357-384. In: Rocha, CFD, HG Bergallo, MV Sluys \& MAS Alves, (Eds). Biologia da Conservação: Essências. São Carlos: Editora RiMa.

Gallego-Ropero, MC, RM Feitosa \& JR Pujol-Luz, 2013. Formigas (Hymenoptera, Formicidae) Associadas a Ninhos de Cornitermes cumulans (Kollar) (Isoptera, Termitidae) no Cerrado do Planalto Central do Brasil. EntomoBrasilis, 6: 97-101. DOI: https://doi.org/10.12741/ebrasilis.v6i1.283

Herrera, HW, L Baert, W Dekoninck, CE Causton, CR Sevilla, $P$ Pozo \& F Hendrickx, 2020. Distribution and habitat preferences of Galápagos ants (Hymenoptera: Formicidae). Belgian Journal of Entomology, 93: 1-6.

Iop, S, VM Caldart, JA Lutinski \& FRM Garcia, 2009. Formigas urbanas da cidade de Xanxerê, Santa Catarina, Brasil. Biotemas, 22: 55-64. DOI: https://doi.org/10.5007/21757925.2009v22n2p55

Jaime, NG, 2010. Levantamentos mirmecofaunísticos em três ambientes antrópicos nos Estados de Goiás e Tocantins, Brasil. Tese (Doutorado em Agronomia: Produção Vegetal). Universidade Federal de Goiás.

Júnior, VB, 2017. Fatores e processos estruturadores das comunidades de formigas (Hymenoptera: Formicidae) de árvores urbanas: uma perspectiva de metacomunidades. Tese (Doutorado em Biodiversidade e Conservação). Universidade Federal da Grande Dourados.

Lutinski, JA, CJ Lutinski, BC Lopes \& ABB Morais, 2014. Estrutura da comunidade de formigas (Hymenoptera: Formicidae) em quatro ambientes com diferentes níveis de perturbação antrópica. Ecología Austral, 24: 229-237. DOI: https://doi.org/10.25260/EA.14.24.2.0.26

Lutinski, JA, C Guarda, CJ Lutinski \& FMR Garcia, 2017. Formigas em ambientes urbanos no sul do Brasil, pp. 397-422. In: Bueno OC, AEC Campos \& MSC Morini, (Eds). Formigas em ambientes urbanos no Brasil. São Paulo: Canal 6 Editora.

Melo, TS, \& JHC Delabie, 2017. Ecologia e conservação da biodiversidade de formigas em ambientes urbanos, pp. 189-240. In: Bueno OC, AEC Campos \& MSC Morini, (Eds). Formigas em ambientes urbanos no Brasil. São Paulo: Canal 6 Editora.

Miranda, M, VB Andrade, GDV Marques \& VSS Moreira, 2006. Mirmecofauna (Hymenoptera, Formicidae) em fragmento urbano de mata mesófila semidecídua. Zoociências, 8: 4954.

Morini, MSC, CB Munhae, R Leung, DF Candiani \& JC Voltolini, 2007. Comunidades de formigas (Hymenoptera, Formicidae) em fragmentos de Mata Atlântica situados em áreas urbanizadas. Iheringia, 97: 246-252. DOI: https://doi.org/10.1590/S0073-47212007000300005

Oliveira, IRP, AN Ferreira, AB Viana Júnior, JO Dantas, MJC
Santos \& MJB Ribeiro, 2016. Diversidade de formigas (Hymenoptera; Formicidae) edáficas em três estágios sucessionais de Mata Atlântica em São Cristóvão, Sergipe. Agroforestalis News, 1: 48-58.

Oliveira, MF \& AEC Campos-Farinha, 2005. Formigas Urbanas do Município de Maringá, PR, e suas implicações. Arquivos do Instituto Biológico, 72: 33-39.

Pacheco, R, CB Munhae \& GP Camacho, 2017. Formigas exóticas em diferentes paisagens urbanas, pp. 190-241. In: Bueno OC, AEC Campos \& MSC Morini, (Eds). Formigas em ambientes urbanos no Brasil. São Paulo: Canal 6 Editora.

Prezoto, F, HH Santos-Prezoto \& MM Castro, 2017. Formigas em ambientes urbanos no sudeste do Brasil: São Paulo, pp. 465-480. In: Bueno OC, AEC Campos \& MSC Morini, (Eds). Formigas em ambientes urbanos no Brasil. São Paulo: Canal 6 Editora.

Ramos, LDS, R Zanetti-Bonetti Filho, JH Delabie, S Lacau, MFS Santos, IC Nascimento \& CGS Marinho, 2003. Comunidades de formigas (Hymenoptera: Formicidae) de serapilheira em áreas de cerrado "stricto sensu" em Minas Gerais. Lundiana: International Journal of Biodiversity, 4: 95-102. DOI: https://doi.org/10.35699/2675-5327.2003.21859

Roani, AH, AM Rizzotto, C Guarda, R Giovenardi \& JA Lutinski, 2019. Formigas em ambientes urbanos da região noroeste do Rio Grande do Sul. Brazilian Journal of Environmental Sciences, 51: 128-140. DOI: https://doi.org/10.5327/Z2176947820190464

Rocha, WO, A Dorval, O Perez Filho, CA Vaez \& ES Ribeiro, 2015. Formigas (Hymenoptera: Formicidae) bioindicadoras de degradação ambiental em Poxoréu, Mato Grosso, Brasil. Floresta e Ambiente, 22: 88-98. DOI: https://doi.org/10.1590/2179-8087.0049

Silva, EJE \& AE Loeck, 1999. Ocorrência de formigas domiciliares (Hymenoptera: Formicidae) em Pelotas, RS. Agrociências, 5: 220-224.

Soares, NS, LDO Almeida, CA Gonçalves, MT Marcolino \& AM Bonetti, 2006. Levantamento da diversidade de formigas (Hymenoptera: Formicidae) na região urbana de Uberlândia, MG. Neotropical Entomology, 35: 324-328. DOI: https://doi.org/10.1590/S1519-566X2006000300005

Soares, NS, 2005. Formigas domiciliares em região urbana de Cerrado e sua diversidade genética. Dissertação (Mestrado em Genética e Bioquímica). Universidade Federal de Uberlândia.

Solis, DR, OC Bueno, TC Moretti \& TF Silva, 2007. Observações sobre a biologia da formiga invasora Paratrechina longicornis (Latreille, 1802) (Hymenoptera, Formicidae) em ambiente urbano brasileiro. Revista Brasileira de Zoociências, 9: 75-80.

Suguituru, SS, MDC Morini, RM Feitosa \& RD Silva, 2015. Formigas do alto Tietê. 1 Edição. Bauru: Canal 6 Editora.

Vital, MR, 2007. Diversidade de formigas (Hymenoptera: Formicidae) em praças urbanas de Juiz de Fora, MG. Dissertação (Mestrado em Ecologia Aplicada à Conservação e Manejo de Recursos Naturais). Universidade Federal de Juiz de Fora.

$\star * * * * * * * * *$
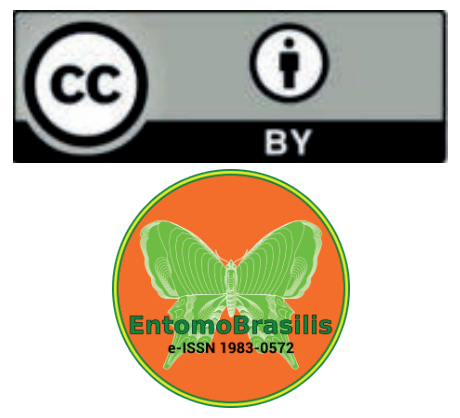

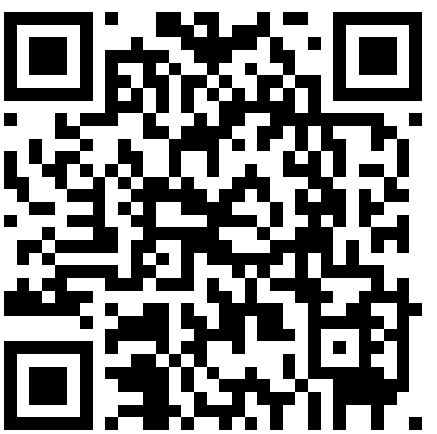

